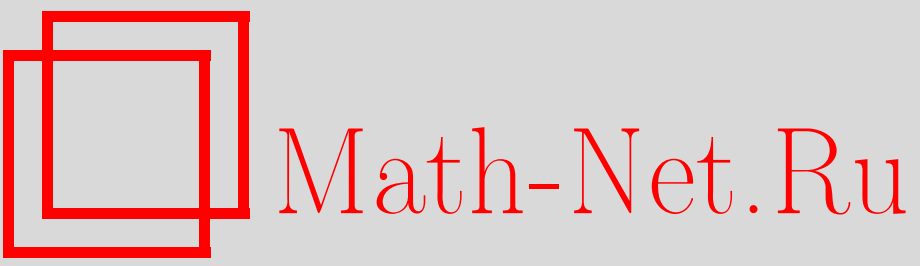

О. А. Олейник, А. А. Самарский, В. И. Ильин, А. Г. Свешников, В. Ф. Бутузов, Аделаида Борисовна Васильева (к семидесятилетию со дня рождения), УМН, 1996, том 51, выпуск 4, 177-178

DOI: https://doi.org/10.4213/rm1563

Использование Общероссийского математического портала Math-Net.Ru подразумевает, что вы прочитали и согласны с пользовательским соглашением

http: //www.mathnet.ru/rus/agreement

Параметры загрузки:

IP: 18.234 .156 .22

26 апреля 2023 г., 16:54:39 


\section{МАТЕМАТИЧЕСКАЯ ЖКИНЬ}

\section{АДЕЛАИДА БОРИСОВНА ВАСИЛЬЕВА \\ (к семидесятилетию со дня рождения)}

10 марта 1996 г. математическая обшественность нашей страны отметила юбилей выдающегося российского математика - профессора кафедры математики физического факультета Московского университета Аделаиды Борисовны Васильевой.

Среди специалистов по качественной теории дифференциальных уравнений А.Б. Васильева занимает видное место. Она - признанный классик в теории сингулярных возмущений, работающий в этой области уже полвека.

А.Б. Василева - талантливая ученица крупнейшего российского математика академика А.Н. Тихонова. В конце сороковых - начале пятидесятых годов А.Н. Тихонов опубликовал цикл работ по дифференциальным уравнениям с малыми параметрами при старшей производной, которые положили начало новому направлению в области дифференциалњных уравнений и математической физики. Позднее это направление стало называться теорией сингулярных возмущений. А.Б. Васильева стояла у истоков этого направления. Ее дипломная работа, а затем кандидатская диссертация выполнялись под непосредственным руководством А.Н. Тихонова и были посвящены задачам, развивающим теорему Тихонова об условиях сходимости решения сингулярно возмущенной задачи к решению вырожденной задачи.

Заложив основы нового направления, А.Н. Тихонов передал эстафету своей молодой ученице. И это направление оказалось в надежных руках.

За короткий срок А.Б. Василева разработала эффективный метод, позволяющий строить равномерные асимптотические приближения для решений сингулярно возмущенной системы обыкновенных дифференциальных уравнений, содержащей быстрые и медленные переменные (такая система получили название тихоновской системы). Суть этого метода состоит в том, что асимптотическое разложение решения началњной задачи для тихоновской системы строится в виде суммы двух рядов по степеням малого параметра - регулярного ряда, дающего приближение для решения вне некоторой окрестности начальной точки, и погранслойного ряда, служащего для описания решения в окрестности начальной точки, где имеет место пограничный слой. Члены погранслойного ряда зависят от растянутого (быстрого) времени и называются пограничны- 
ми функциями. Поэтому и сам метод получил название метода пограничных функций. Он был развит А. Б. Васильевой не только для начальных, но и для краевых задач, в которых может возникать пограничный слой на обоих конца отрезка и может появляться внутренний переходный слой.

Метод пограничных функций считается теперь классическим методом в теории сингулярных возмущений и по праву носит имя ее создателя - А.Б. Васиљевой. В 1961 г. за работы по методу пограничных функций А.Б. Васильевой была присуждена ученая степень доктора физико-математических наук. В последующие годы А. Б. Васильевой и ее учениками метод пограничных функций был распространен на интегро-дифференциальные уравнения, дифференциальные уравнения с малым запаздыванием и разностные уравнения с малым шагом, на все основные типы уравнений с частными производными. Вокруг А.Б. Васильевой сложился мощный научный коллектив, занимающийся проблемами теории сингулярных возмущений. В него входят многочисленные ученики А.Б. Васильевой, работающие в Московском университет и за его пределами, ученики ее учеников, аспиранты, студенты. Более тридцати лет она руководит имеющим всероссийскую известность научно-исследовательским семинаром, на котором прошли апробацию десятки кандидатских и докторских диссертаций, выполненных по тематике теории сингулярных возмушений в МГУ и других учебно-научных центрах нашей страны и ближнего зарубежья. Непосредственно под ее руководством подготовлено 25 кандидатских диссертаций, шесть ее учеников стали докторами наук.

Имя А. Б. Васильевой широко известно среди ученых математиков не только в нашей стране, но и во всех ведущих странах мира. Неоднократно она докладьвала свои результаты на крупных международных математических форумах. Ею опубликовано около 200 научњых работ, в том числе четыре монографии. Первые три написаны совместно с В. $Ф$. Бутузовым, а последняя, опубликованная в 1995 г. в США издательством SIAM, - совместно с В. Ф. Бутузовым и Л. В. Калачевым. В последние годы А.Б. Васильевой получены новые крупные результаты по существованию, построению асимптотик и устойчивости контрастных структур, описываемых решениями дифференциальных уравнений, испытываюшими резкие изменения типа скачков, всплесков и т.д. Это направление в теории сингулярных возмущений в настоящее время переживает период бурного развития, здесь сосредоточены усилия многих известных специалистов, занимающихся теорией сингулярных возмущений и ее приложениями к задачам химфизики, биофизики, синергетики, а первые результаты в этом направлении были получены А. Б. Василевой почти тридщать лет назад.

Профессор А.Б. Васильева хорошо известна многим поколениям студентов физического факультета МГУ, где она вот уже более сорока лет читает лекции по общим курсам математики. Ее глубокие по содержанию и яркие по исполнению лекции неизменно пользуются популярностью у студентов. А.Б. Василева - автор учебника "Дифференциальные уравнения" (совместно с А.Н. Тихоновым и А. Г. Свешниковым), получившего широкое признание в вузах нашей страны и за рубежом, где он переведен на английский язык, и учебного пособия "Интегральные уравнения" (совместно с Н. А. Тихоновым).

А.Б. Васильева - человек разносторонних интересов, неутомимый путешественник, тонкий знаток и ценитель различных видов искусства. Особенно покоряет ее увлеченность музыкой. Она создала эквиритмические переводы текстов вокальных произведений Брамса, Леве и других композиторов. Переводы были опубликованы издательством "Музыка", и теперь эти вокальные произведения исполняются профессиональњгми артистами на русском язьке.

Аделаида Борисовна Васильева полна сил и творческих планов. Поздравляя ее с юбилеем, мы желаем ей доброго здоровья, счастья и еще многих-многих лет такого же творческого горения и служения отечественной науке и образованию.

О.А. Олейник, А.А. Самарский, В.И. Ильин, А.Г. Свешников, В. Ф. Бутузов 